\title{
Green dyeing of microwave treated silk using coconut coir based tannin natural dye
}

\author{
DOI: 10.35530/IT.071.03.1666
}

\author{
SHUMAILA KIRAN \\ SHAHID ADEEL \\ MUHAMMAD SAJJAD YOUSAF \\ NOMAN HABIB
}

\author{
ATYA HASSAN \\ MUHAMMAD ABDUL QAYYUM \\ MUHAMMAD ABDULLAH
}

\section{ABSTRACT - REZUMAT}

\section{Green dyeing of microwave treated silk using coconut coir based tannin natural dye}

The resurgence of natural dyes is gaining fame in textile industry due to eco-friendly nature. The present study was done to investigate the Coconut coir as natural dye (tannin) for silk dyeing under Microwave (MW) treatment following the optimization of experimental parameters. Isolation of colorant was carried out in aqueous, acidic and organic media (methanol) under influence of MW treatment up to 6 minutes. Dyeing of silk was carried out having irradiated and unirradiated extracts. Good colour strength was achieved by dyeing unirradiated silk using methanolic extract under MW treatment for 4 minutes at $75^{\circ} \mathrm{C}$. The optimal dyeing was achieved at 75 minutes at $\mathrm{pH} 8$ while keeping fabric liquor ratio $1: 25$ having $5 \mathrm{~g} / 100 \mathrm{ml}$ table salt as an electrolyte. For development of shades, salts of $\mathrm{Al}$ and Fe and Tannic acid were used as pre- and post-chemical mordants and Acacia, Pomegranate, Turmeric and Henna as pre- and post-biomordents. Acacia (6\%) as pre-bio mordant and Turmeric (6\%) as post-bio mordant considerably improved the colour strength at optimal conditions utilizing irradiated extract of coconut coir (tannin) and un-irradiated silk under MW treatment at 4 minutes. ISO-standard shows good colour fastness and colour strength at optimal conditions using Acacia and Turmeric as bio-mordents. This research work gives information about tannin extracted from Coconut coir has great potential to dye silk fabric to produce reddish-brown colour under the influence of microwave treatment. FTIR spectral study revealed chemical changes in the silk fabric treated with microwave radiations.

Keywords: coconut coir, microwave treatment, dyeing, silk, chemical mordents, bio-mordants, K/S value, colour fastness, FTIR

\section{Vopsirea ecologică a mătăsii tratate cu microunde folosind colorant natural tanin din nucă de cocos}

Coloranții naturali câștigă notorietate în industria textilă datorită naturii ecologice a acestora. Studiul de față a fost realizat pentru a investiga nuca de cocos în calitate de colorant natural (tanin), pentru vopsirea mătăsii sub tratament cu microunde (MW), în urma optimizării parametrilor experimentali. Izolarea colorantului a fost realizată în mediu apos, acid și organic (metanol), sub influența tratamentului MW, până la 6 minute. Vopsirea mătăsii s-a realizat cu extracte iradiate și neiradiate. O rezistență bună a culorii a fost obținută prin vopsirea mătăsii neiradiate folosind extract metanolic sub tratament $M W$, timp de 4 minute la $75^{\circ} \mathrm{C}$. Vopsirea optimă a fost obținută după 75 minute cu un pH 8 , păstrând un raport de flotă de 1:25, folosind $5 \mathrm{~g} / 100 \mathrm{ml}$ sare de masă ca electrolit. Pentru dezvoltarea nuanțelor, sărurile de $A /$ și $F e$ și acidul tanic au fost utilizate ca pre- și post-mordanți chimici, iar salcâmul, rodia, curcuma și henna ca pre- și postbiomordanți. Salcâmul (6\%) ca pre-biomordant și curcuma (6\%) ca post-biomordant au îmbunătățit considerabil rezistența culorii în condiții optime, folosind extract iradiat de nucă de cocos (tanin) și mătase iradiată sub tratament MW la 4 minute. Conform standardului ISO se obține o rezistență a culorii în condiții optime, folosind salcâmul și curcuma ca bio-mordanți. Această lucrare de cercetare oferă informații despre taninul extras din nuca de cocos, care are un potențial semnificativ de a vopsi țesăturile din mătase, pentru a produce o culoare maro roșiatică sub influența tratamentului cu microunde. Studiul spectral FTIR a evidențiat modificări chimice ale țesăturii din mătase tratate cu radiații de microunde.

Cuvinte-cheie: nucă de cocos, tratament cu microunde, vopsire, mătase, mordanți chimici, bio-mordanți, valoare K/S, rezistența culorii, FTIR

\section{INTRODUCTION}

Natural dyes contain pure colorant components, which are non-hazardous to environment. Mostly, these colorants are obtained from self-growing plants and non-traditional crops [1]. Natural colours are famous for utilizing in colouring of food, leather and natural protein fabrics such as silk, wool and cotton [2], as synthetic dyes generate hazardous waste which is harmful for living environment [3-5]. But majority of common hues are taken from various parts of plants such as roots (Morinda tentoria), bark (Azadirachta indica), flowers (Solidago grandis) and leaves (Tectona grandis) etc. [6]. The colour of these dyes enhanced with the passage of time unlike their synthetic counter parts which fade with time [7]. People demand that colors must have appropriate 
shades and have capacity to fix with the substrate strongly [8]. The shade of coloured substance may not have influenced by drawn out presentation to light, soap, water and colour must have colour fastness properties [9]. Synthetic dyes are hazardous for the environment and are difficult to degrade [10]. Natural colorants are renewable, agro-renewable, and biodegradable, do not cause disposal problem because their wastes become the part of fertilizers and do not pose any threat to food [1]. Natural dyes are eco-friendly and eco-label in nature [1]. Application of natural dyes for textile fabrics acquire some techniques to utilize. Dyeing parameters are, therefore, necessary for obtaining ideal shades for textile processing [11].

Many laboratory techniques are to be utilized for enhancing the extraction of colorant, dyeing behaviour, colour properties, dye sorption, colour fastness and dye uptake for fibers [9]. Radiation is the proliferation and discharge of light as waves through various media. The medium might be a few materials or space. There are diverse sorts of radiation, for example, UV [12], gamma [13], microwave, ultrasonic [14-15]. The microwave heat is very fast technique because of no loss of heat and is safe to use. Microwave radiations had many advantages such as low cost, increase of colour fastness, dye uptake and consumed less energy, power and time [16]. It was observed that by increasing the power up to 700 increased the rate of extraction and give better yield. Microwave heat is distributed uniformly throughout the material and conventional or traditional heating only heat up the surface of material. Microwave radiations are the power source of noncontact heating and in the microwave field the substance that have permanent dipoles to rotate [17].

Silk is the insect fiber which is obtained from silkworm and used as textile fiber. Historically the silk fiber has been referred to as the queen of textiles [18]. Silk fabrics due to excellence performance such as softness, smoothness, luster, breathing ability, comfortableness and hygroscopicity have been used as a textiles material for thousands of years [12]. Coconut coir is a new dye yielding plant whose common name, scientific name and plant family is coir [19] Cocos nucifera and Arecaceae (Plam), respectively [20]. The husk contains tannin which acts as

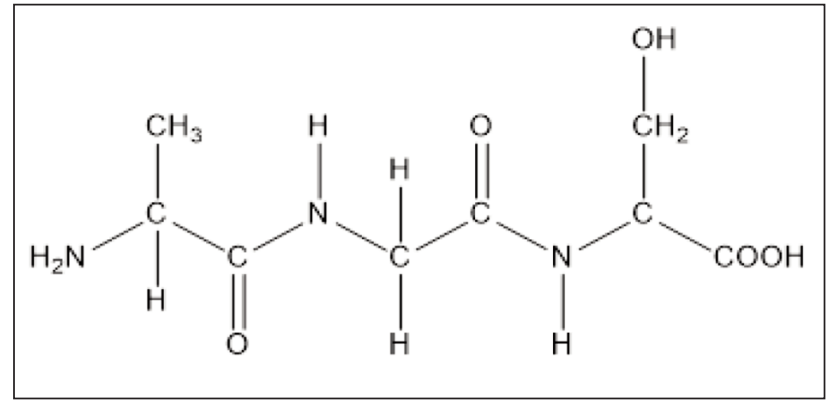

a colouring material to give brown colour on natural fabrics [21]. The alcoholic extracts of coconut husk possess antifungal and antimicrobial activities. It contains tannin as natural colorant which is used for dyeing of wool, silk and cotton (figure 1) [22].

Keeping in view the importance of natural colorants, the present study was focused:

1. To explore the extraction of microwave radiation for isolation and addition of herbal based bio-mordants of colorant from coconut coir using different media under microwave radiations.

2. To develop new shades using exploring of chemical and bio-mordents.

3. To improve the colour fastness properties of silk fabric using chemical and bio mordents.

\section{EXPERIMENTAL WORK}

\section{Materials and methods}

Coconut (Cocos nucifera) coir was collected from the Local Market Faisalabad, Pakistan. The coir was washed with water and dried under shade and cut into small pieces. The plant sources ground finely and went through a sifter of 20 work size to get powder of uniform size and stored in a plastic bag for further process of silk dyeing. Pre-treated silk fabric is purchased from local silk market in Fasialabad, Pakistan was dyed from the coconut coir.

\section{Optimization of extraction conditions under microwave irradiation}

The process of extraction of aqueous, acidic and organic (methanol) extracts were obtained from coconut coir by boiling $4 \mathrm{~g}$ of powder of coconut coir in $100 \mathrm{ml}$ of water for $60 \mathrm{~min}$. After boiling the flask were cooled and filtered. The filtrate was utilized for dyeing of natural silk fabric was treated with microwaves up to 1 to $6 \mathrm{~min}$. in a microwave oven (Orient Model ME-732 K) with power $800 \mathrm{~W}$ having frequency $450 \mathrm{MHz}$. Dyeing process was followed for treated and untreated silk fabrics [23].

It was found that optimized dyeing on silk fabric was achieved by utilizing methanolic media with $4 \mathrm{~min}$. treated with microwave radiations keeping temperature $75^{\circ} \mathrm{C}$ [24].

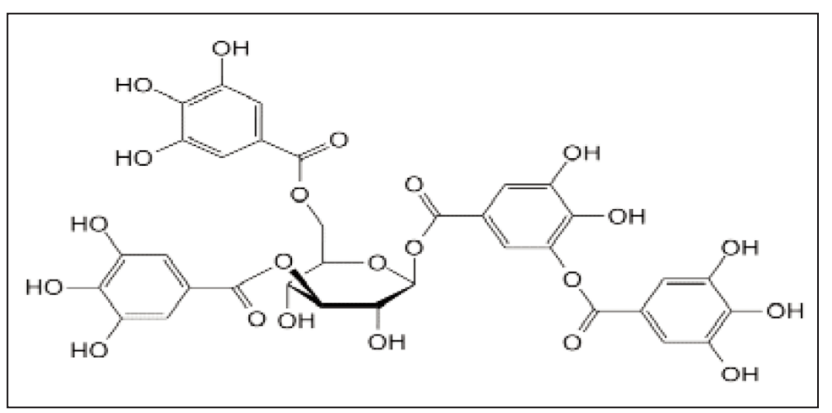

$\boldsymbol{b}$

Fig. 1. Structure of: $a-$ silk; $b-$ tannin 


\section{Different dye bath parameters with mordents}

For optimum dyeing, different parameters like $\mathrm{pH}$ (1 to 9), Time (25 to $85 \mathrm{~min}$.), Temperature (25 to $\left.85^{\circ} \mathrm{C}\right)$ and $\mathrm{NaCl} \& \mathrm{Na}_{2} \mathrm{SO}_{4}(1-11 \mathrm{~g} / 100 \mathrm{ml})$ were applied [25]. In exhaust dyeing, salt is used as an electrolyte for level and uniform dyeing [26]. Dyeing process was completed for $75 \mathrm{~min}$. at $75^{\circ} \mathrm{C}$ [27]. Irradiated silk and un-irradiated silk was dyed by this dyeing process. Extracts of different chemical mordents (1 to $11 \mathrm{~g} / 100 \mathrm{ml}$ ) like $\mathrm{Al}$ [28], Fe [29] and Tannic acid and bio-mordents ( 1 to $11 \mathrm{~g} / 100 \mathrm{ml}$ ) like henna, acacia [12], pomegranate and turmeric [30] were also applied to improve in colour strength and fastness properties [31].

\section{Measuring colour strength and colour fastness properties}

Microwave treated and untreated silk fabrics were observed for colour strength and Lab values through Kubelka Munk equation computed in Spectra Flash (SF 600) at laboratory of the Noor Fatima Fabrics, Faisalabad, Punjab, Pakistan. Colour strength values were achieved from the equation [K/S $=(1-R) 2 / 2 R]$. ISO standard method for light (ISO 105-Bo2), rubbing (ISO 105-X12), washing (ISO 105 C03), dry cleaning (ISO 105D 01) and perspiration (ISO 105 EO4) fastness tests were used to investigate the colour fastness properties of dyed silk.

\section{FTIR analysis}

FTIR analysis was done to investigate the influence of the treatment with microwaves on the chemical structure of silk fibers. Experiments with silk fabric in a wet state under microwave irradiation for various lengths of time (1-6 min.) were carried out. This analysis uses infrared light to scan and observe chemical properties of samples. Samples were prepared using optimum irradiated microwave treatment for both silk and tannin dye solution. Control sample was also subjected to FTIR.

\section{RESULTS AND DISCUSSION}

Microwave irradiation improved the colour depth characteristics from the extract of coconut coir in methanolic media, when compared with other dyeing media. The results are shown in figure 2.

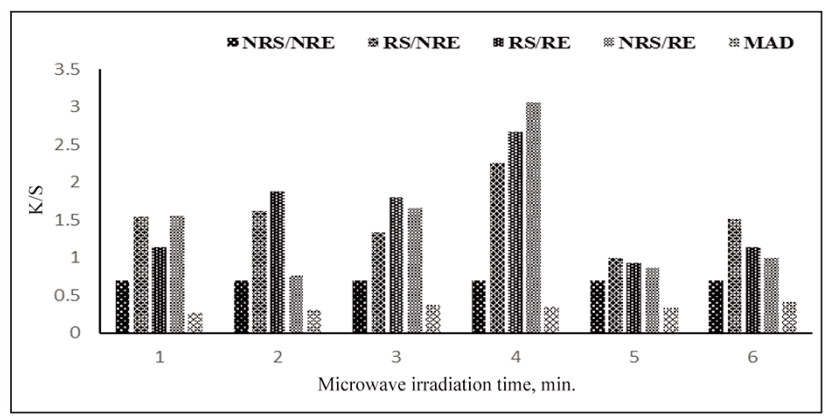

Fig. 2. Microwave treatment of pre-treated silk dyeing by methanolic extract of coconut coir: NRS - non-irradiated silk; NRE - non-irradiated extract; RS - irradiated silk; $\mathrm{RE}$ - irradiated extract
Colour characteristics of dyed silk fabric from the coconut coir in a methanol medium was enhanced by the presence of colouring part in coconut coir (phenol) which is more soluble in methanol medium [32]. During dyeing, colouring part from the coconut coir (tannin) makes strong bond with amino and carboxylic groups which are present in silk fabric. In other media impurities like dust, leaves of plants might be connected with the fabric and dye bath not make firm bonding resulted less colour depth [33]. In figure 2 result shows that high colour depth was achieved by utilizing MW treatment of $4 \mathrm{~min}$. on the silk fabric [34]. Microwave treated fabric enhanced the colour strength on the fabric by using pomegranate (Punica granatum L.) mentioned in literature [35]. However, high time microwave treatment of silk fabric not effect on the colour yields (figure 2). Similarly, low time contact of fabric under MW treatment not force the dye particles to sorb towards the fabric surface and treatment of fabric with microwave irradiation for more time period degrade the dye particles as well as he fabric surface, resulted decrease in yield of colour on silk fabric [36]. Overheating, from microwave treatment of fabric also swells the fabric surface, by which colour particles not make proper bonds with fabric [11].

\section{Optimization of experimental parameters}

$\mathrm{pH}$ in the dying bath also plays an important role in dyeing process. At optimum $\mathrm{pH}$ high colour strength is achieved on the coloured silk fabric. Role of optimum $\mathrm{pH}$ is that it accelerates the dye molecules towards the fabric surface for sorption. In figure 3, a data gives information that at $8 \mathrm{pH}$ maximum colour strength is measured as compared to the other $\mathrm{pH}$ conditions. Silk fabric is damaged on the more acidic $\mathrm{pH}$ because acid damage the silk structure [19]. So moderate $\mathrm{pH}$ was suitable for silk dyeing b/c dye molecules jump toward the fabric surface for sorption [37]. Moderate $\mathrm{pH}$ not damages the fabric surface [17]. Temperature is an important tool for the sorption of the dye particles to rush toward the fabric surface during dyeing process. Figure $3, b$ shows that best temperature for the dyeing of un-treated silk fabric under the influence of MW treatment was $75^{\circ} \mathrm{C}$ using treated methanol extract of coconut coir. It is evident from figure 5 at $75^{\circ} \mathrm{C}$ that $\mathrm{MW}$ radiations not accelerate colour particles to move on the fabric surface due to low rate of striking of dye particles and thus low colour values are obtained. Similarly, at high temperature $\left(85^{\circ} \mathrm{C}\right)$ fabric swell and change in structure both in fabric and dye particles resulted poor colour yield. Up to $75^{\circ} \mathrm{C}$, dye particles act as a unit molecule and properly absorbed on the silk fabric surface revealed the dark shade and optimal colour strength achieved [38]. In dyeing process, time parameter plays a significant impact on the fabric surface. When molecules of dye move on fabric surface it require time for making bond with fabric surface and for good sorption of the dye molecules [39]. Data given in figure 3, $C$ shows that optimal time for dye molecules to rush toward fabric for good sorption is $75 \mathrm{~min}$. Good 
colour strength of dyed silk obtained from spectra flash was at 75 min. in methanolic extract of coconut coir tannin based dye. Low dyeing time may not interact the dye molecules to rush toward the silk fabric. It may also reduce the kinetic energy of the dye molecules to sorption on the silk fabric [40]. Similarly, more dyeing time degrade the silk fabric and not favoured for sorb of the level dyeing on silk fabric. Long dyeing time may weak the $\mathrm{H}$-bonding between the dye molecules and silk fabric [41]. Hence, 75 min. is the suitable dyeing time for silk dyeing for good colour strength [11]. Adding of electrolyte in dye bath resulted in enhanced dyeing yield on silk fabric. Silk fabric produced poor colour strength contraction with colouring particle and less dye adsorbed on the fabric surface without using salt in dyeing process. However, adding electrolyte increases the dye particle adsorption on fabric. In figure $3, d$ shows that Table salt using in dyeing at $5 \mathrm{~g} / 100 \mathrm{ml}$ increased dye yield as compared the Glauber salt. It might be due to the fact that silk fabric acquired negative charge in methanolic medium and dye anions repulsion increased by fabric and not make firm bonding by colouring particles from dye towards the silk fabric [9, 42-43]. Role of using electrolyte in dyeing process is that it increases the anions on the fabric surface and minimize the force of repulsion between fabric and negative colouring particle charges and enhance the colour depth from dye bath toward the fabric surface. Low salt concentration ( 1 and $3 \mathrm{~g} / 100 \mathrm{ml}$ ) and high amounts $(7-11 \mathrm{~g} / 100 \mathrm{ml})$ not properly shift the dye particles towards the dye fabric surface because the dye equilibrium not produced between dye and fabric

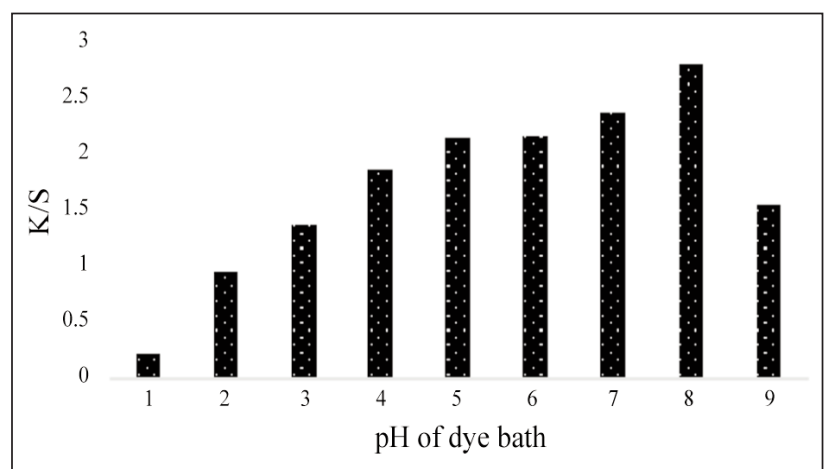

a

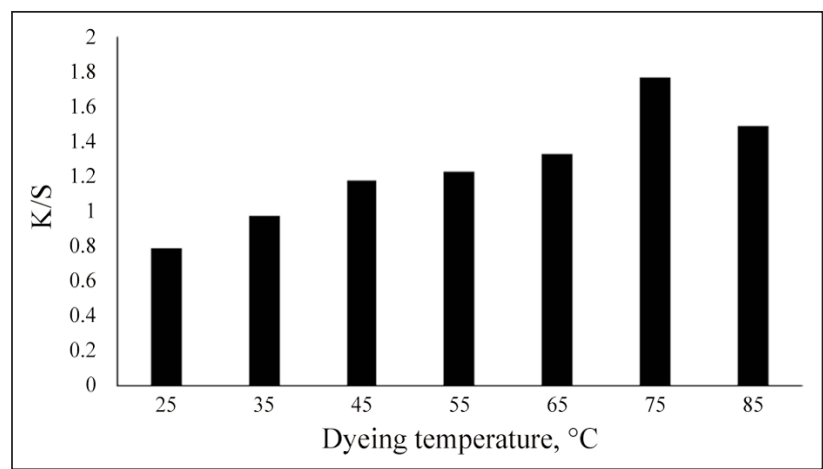

c therefore, less light shades achieved. In dyeing, treatment of microwave radiations decreases the salt consumption on the silk fabric [14]. Therefore, using $5 \mathrm{~g} / 100 \mathrm{ml}$ table salt enhanced the rate of exhaust dyeing of un-treated silk (NRS) with methanol extract of coconut coir (RE) under the influence of microwave treatment and utilized the fabric for future process for improvement in colour strength.

\section{Effect of chemical and bio-mordents on dyeing of silk fabric}

The pre-mordenting behavior of different chemical mordents (salts of Al \& Fe, Tannic acid) and bio-mordents (Acacia, Turmeric, Henna and Pomegranate) is shown in figure 4. Each chemical and bio-mordents enhanced colour strength on silk fabrics dyed with methanolic extract of coconut coir. However, Acacia (6\%) enhanced colour depth characteristics as compared to other mordents, when silk dyed from methanolic extract of coconut coir (figure 4,a). It might be due to the reason that dye particle tannin present in both coconut coir and acacia bark [43] results high shade strength and make firm bonding between fabric carboxylic group and phenolic groups present in the dye molecules [10]. In post-mordenting, Turmeric $(6 \%)$ exhibited good colour strength on the silk fabric as compared to the other chemical (Fe, Al and Tannic acid) and Bio (Henna, Pomegranate and $A$. nilotica bark) mordents (figure $4, b$ ). Turmeric as post-mordant makes strong $\mathrm{H}$-bonding with tannin dye particles and fabric surface. Turmeric also had potential to making complex bond with dye and fabric surface by this process, more colour sorbed on silk fabric and yellow colour produced rather than the

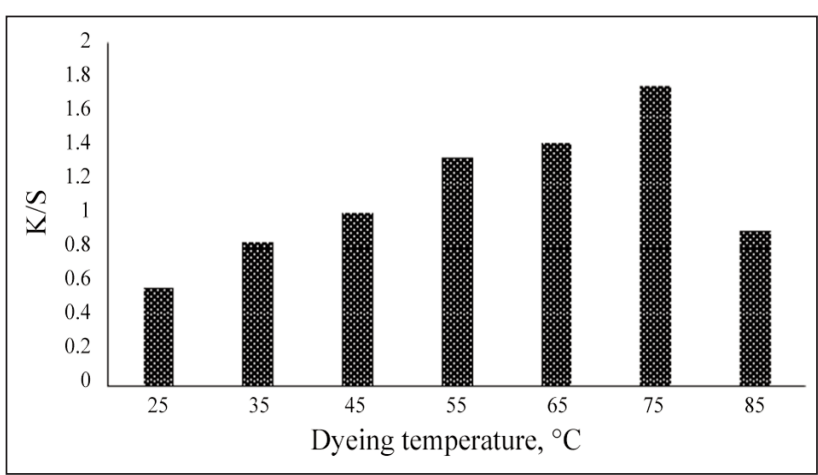

b

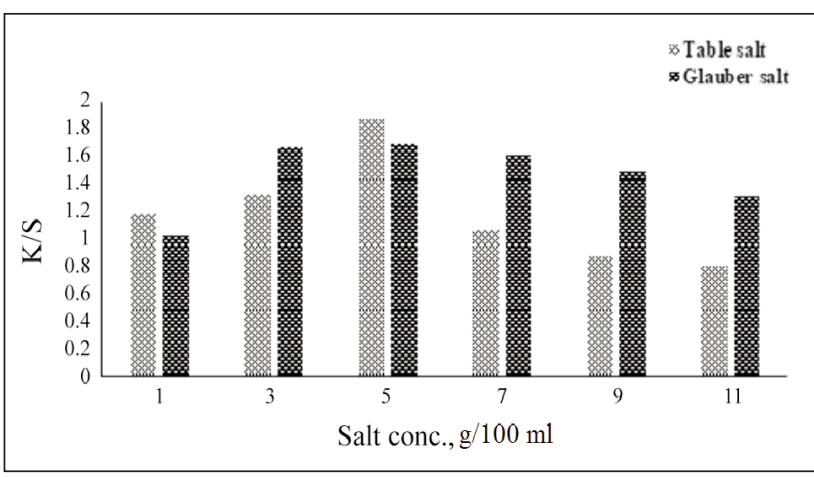

d

Fig. 3. Impacts of dyeing variables on the coloured silk fabric (NRS/RE) by extract of methanolic coconut coir 


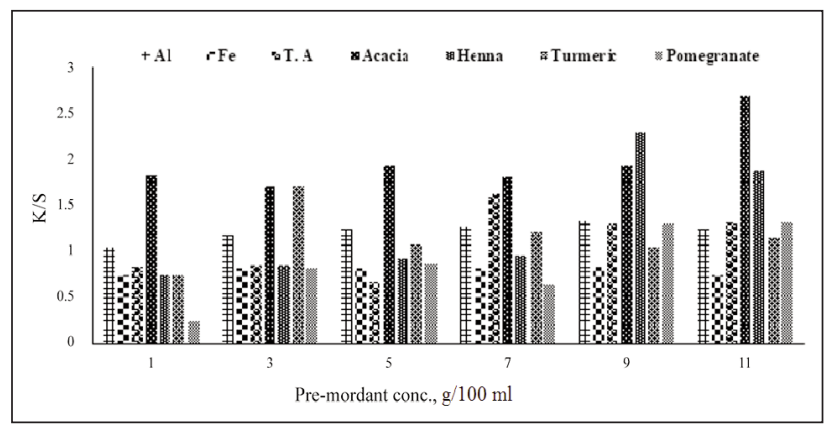

a

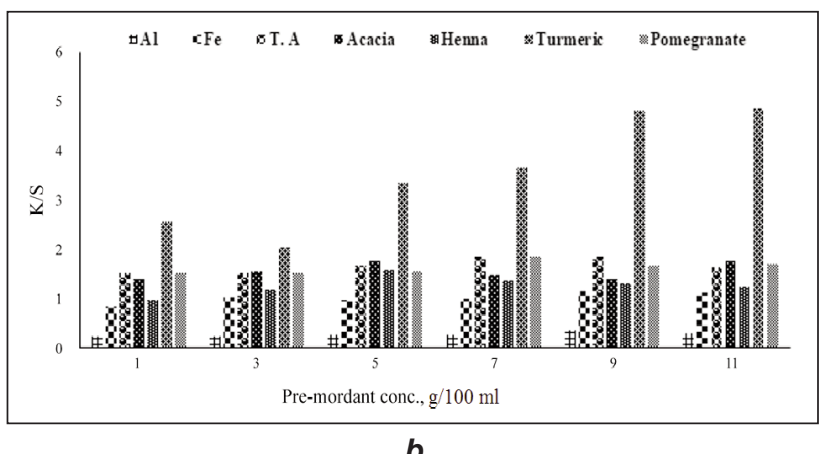

b

Fig. 4. Microwave treatment on the optimum silk dyed fabric 4 minutes (NRS/RE) of: $a$ - pre-mordants; $b$ - post-mordants

other mordents applied on the fabric with good shades strength [44-45]. It is found that low \% of chemical and bio-mordant using in silk dyeing may not made a firm stable complex with silk fabric and during washing easily washed the mordents from fabric surface and low K/S values achieved [9]. Thus, overall bio-mordents established high colour characteristics and fastness properties rather than the chemical mordents under the MW treatment of silk fabric [46]. Furthermore, Bio-mordents are more ecofriendly, sustainable and greener for the using silk dyeing under MW treatment [19].

\section{Fastness properties}

The fastness properties results show under the influence of MW treatment of methanol extract of coconut coir using untreated silk fabrics enhanced strength of colour and produced high colour depths (tables 1 and
2). This is because that methanolic extract of coconut coir for 4 minutes and mordented silk fabric make firm bonding with dye and silk fabric utilizing bio-mordents as compared to the chemical mordents due to the conjugation double bonds in natural dye (tannin in coconut coir) and auxochrome with stable complex formation of dye and chemical mordant on the silk fabric and strong $\mathrm{H}$-bonding with bio-mordents. They have resistance to eject colorant during applying fastness properties such as washing, rubbing and light [47].

Better colour strength achieved on the silk fabric to make good strength bond complex between dye and metal due to phenolic groups and double conjugate bond which present in dye molecules [48].Tannin which also present in dye molecules also had double conjugate bond helps to make firm bonding formation when bio-mordents are applied on silk fabric to

EFFECT OF CHEMICAL MORDANT BY MICROWAVE TREATMENT ON COLOUR STRENGTH VALUES OF UNTREATED SILK FABRIC UTILIZING TREATED EXTRACT OF METHANOLIC COCONUT COIR ON OPTIMAL PARAMETERS

\begin{tabular}{|c|c|c|c|c|c|c|c|c|c|c|c|c|c|c|}
\hline \multirow{3}{*}{$\begin{array}{l}\text { Chemical } \\
\text { mordant }\end{array}$} & \multicolumn{7}{|c|}{ Pre-mordanting } & \multicolumn{7}{|c|}{ Post-mordanting } \\
\hline & \multirow{2}{*}{ LF } & \multirow{2}{*}{ WF } & \multirow{2}{*}{ DRF } & \multirow{2}{*}{ WRF } & \multicolumn{2}{|c|}{ Perspiration } & \multirow{2}{*}{$\begin{array}{l}\text { Dry } \\
\text { clean }\end{array}$} & \multirow{2}{*}{ LF } & \multirow{2}{*}{ WF } & \multirow{2}{*}{ DRF } & \multirow{2}{*}{ WRF } & \multicolumn{2}{|c|}{ Perspiration } & \multirow{2}{*}{$\begin{array}{l}\text { Dry } \\
\text { clean }\end{array}$} \\
\hline & & & & & acid & alkaline & & & & & & acid & alkaline & \\
\hline $\mathrm{Al}$ & $4-5$ & 4 & 5 & 4 & $4-5$ & 4 & 4 & $4-5$ & $3-4$ & 4 & 3 & 4 & 3 & 4 \\
\hline $\mathrm{Fe}$ & 4 & $3-4$ & 4 & $3-5$ & 4 & $4-5$ & 5 & 4 & $4-5$ & 4 & $3-4$ & $4-5$ & 4 & $4-5$ \\
\hline TA & 4 & 4 & 5 & 4 & $4-5$ & 4 & $4-5$ & $3-4$ & $4-5$ & $4-5$ & $4-5$ & $3-4$ & 3 & 4 \\
\hline
\end{tabular}

EFFECT OF BIO MORDANT BY MICROWAVE TREATMENT ON COLOUR STRENGTH VALUES OF UNTREATED SILK FABRIC UTILIZING TREATED EXTRACT OF METHANOLIC COCONUT COIR ON OPTIMAL PARAMETERS

\begin{tabular}{|c|c|c|c|c|c|c|c|c|c|c|c|c|c|c|}
\hline \multirow{3}{*}{ Bio-mordant } & \multicolumn{7}{|c|}{ Pre-mordanting } & \multicolumn{7}{|c|}{ Post-mordanting } \\
\hline & \multirow{2}{*}{ LF } & \multirow{2}{*}{ WF } & \multirow{2}{*}{ DRF } & \multirow{2}{*}{ WRF } & \multicolumn{2}{|c|}{ Perspiration } & \multirow{2}{*}{$\begin{array}{l}\text { Dry } \\
\text { clean }\end{array}$} & \multirow{2}{*}{ LF } & \multirow{2}{*}{ WF } & \multirow{2}{*}{ DRF } & \multirow{2}{*}{ WRF } & \multicolumn{2}{|c|}{ Perspiration } & \multirow{2}{*}{$\begin{array}{c}\text { Dry } \\
\text { clean }\end{array}$} \\
\hline & & & & & acid & alkaline & & & & & & acid & alkaline & \\
\hline Acacia & $4-5$ & 4 & 5 & 4 & $4-5$ & 4 & 4 & $4-5$ & $3-4$ & 4 & $3-4$ & 4 & 4 & $3-4$ \\
\hline Henna & 4 & $3-4$ & 4 & $3-4$ & $3-4$ & $4-5$ & $4-5$ & 4 & $3-4$ & $4-5$ & 4 & $4-5$ & 4 & $4-5$ \\
\hline Turmeric & 4 & 4 & 5 & 4 & $4-5$ & 4 & $4-5$ & $3-4$ & $4-5$ & $4-5$ & 4 & $3-4$ & 3 & 4 \\
\hline Pomegranate & $3-4$ & $4-5$ & 4 & $3-4$ & 4 & $3-4$ & 4 & $4-5$ & 4 & 4 & $3-4$ & $4-5$ & $3-4$ & 4 \\
\hline
\end{tabular}




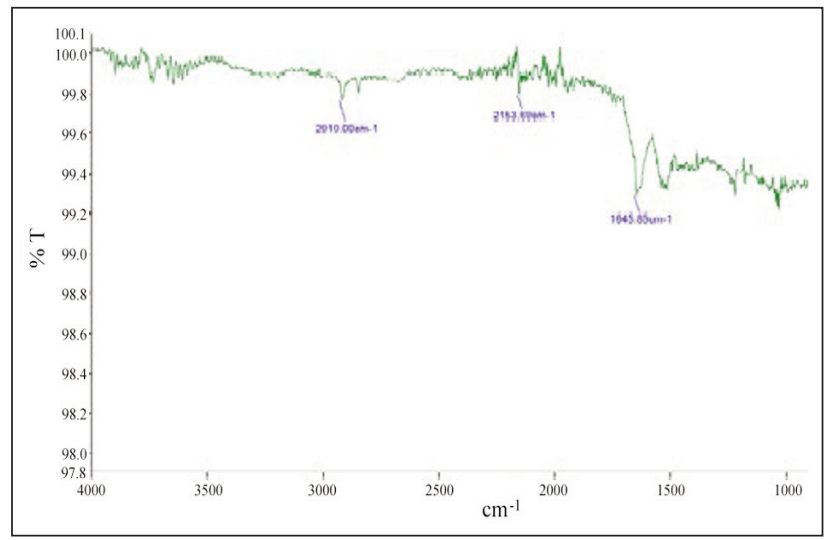

a

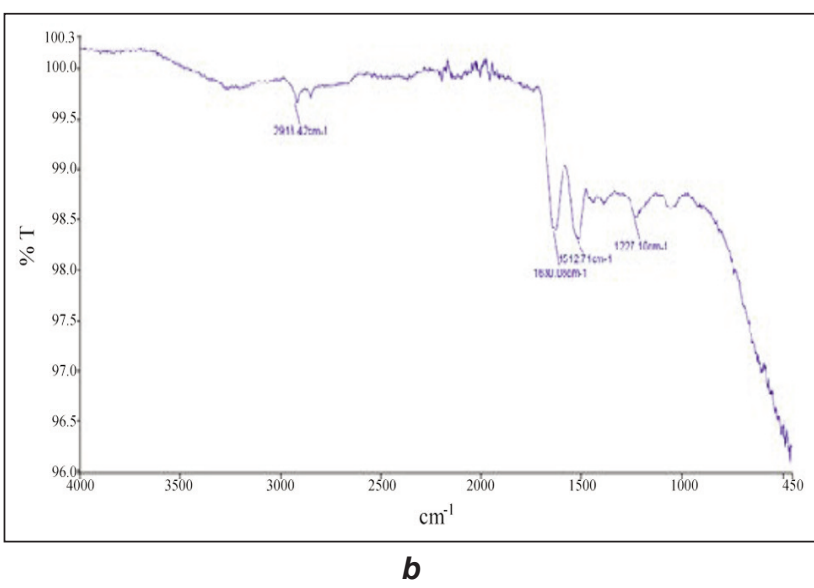

b

Fig. 5. FTIR of: $a$ - untreated silk; $b$ - microwave treated silk

improve the colour strength values [15]. Moreover, microwave treatment has ability to plays a major role enhancing colour fastness on silk fabrics. Hence, during silk dyeing MW treatment is greener, environment friendly and clean process that improved the fastness properties using coconut coir tannin based natural dye for silk dyeing [12].

\section{FTIR analysis}

FTIR analysis of untreated silk fabric and microwave treated silk fabric FTIR-ATR dyed with natural tannin dye extracted from Coconut coir are given in figure 5 . As it can be seen from figure 5, there are not any detectable significant changes in the FTIR spectra properties of microwave treated silk fabric after when compared with undyed silk fabric. According to FTIR spectra, the peaks ranged from $1630.08 \mathrm{~cm}^{-1}$, $1512.71 \mathrm{~cm}^{-1}, 1227.10 \mathrm{~cm}^{-1}$ due to $\mathrm{C}-\mathrm{C}, \mathrm{C}-\mathrm{N}$, and $\mathrm{N}-\mathrm{H}$ stress, are present in both untreated and microwave-treated silk fabrics depicting that MW radiation has nothing to do with the surface of the silk fabric chemically, It just physically modifies the structure of silk fabric which in turn enhanced the dye uptake capacity of silk fabric, resulting in improved colour shades of silk fabric.

\section{CONCLUSIONS}

It has been found that MW treatment during extraction and dyeing process of silk fabric by using natural coconut coir-based tannin dye has potential to dye silk fabric. This method is eco-friendly, green, less cost and less time-consuming process. Microwave assisted dyeing of silk fabric with methanolic extract of coconut coir using chemical and bio-mordants achieved reddish brown colour shades. The gaining of same colour via synthetic dyes is found to be more hazardous and non-ecofriendly. Methanolic extract of coconut coir at $\mathrm{pH} 8$ for $4 \mathrm{~min}$. under MW treatment using $\mathrm{NaCl}(5 \mathrm{~g} / 100 \mathrm{ml})$ gave a good color strength and darker shade by dyeing unirradiated silk fabric for $75 \mathrm{~min}$. at $75^{\circ} \mathrm{C}$. Chemical mordants ( $\mathrm{Al}, \mathrm{Fe}$ and Tannic acid) and bio-mordants such as Henna, Pomegranate, Acacia and Turmeric also applied to improve the colour strength and make strong bonding with silk fabric but bio-mordents like Acacia bark gave excellent colour and high K/S values. Furthermore, MW treatment has also tendency to improve the colour strength on silk using coconut coir extract as a natural dye under optimum conditions. More than that, the use of bio-mordants is non-hazardous for health and environment, green, eco-label and is cheaper for dyeing.

\section{ACKNOWLEDGEMENTS}

We are highly thankful to UNESCO for providing us funding to conduct the studies under PhosAgro/UNESCO/IUPAC/ GCUF Scheme Project No. 128. We are also thankful to Mr Zafar Iqbal Manager Noor Fatima Fabrics Faisalabad Pakistan and Mr Muhammad Abbas Chief Executive Harris Dyes and Chemicals Faisalabad Pakistan for technical and scientific guidance at industrial lab scale for running a part of UNESCO project.

\section{REFERENCES}

[1] Ibrahim, A.N., et al., Enhancing the UV protection and antibacterial properties of polyamide-6 fabric by natural dyeing, In: Textiles and Light Industrial Science and Technology, 2013, 2, 36-44

[2] Mongkholrattanasit, R., et al., Dyeing, fastness, and UV protection properties of silk and wool fabrics dyed with eucalyptus leaf extract by the exhaustion process, In: Fibers \& Textiles in Eastern Europe, 2011, 19, 94-99

[3] Gulzar, T., Kiran, S., Abrar, S., Rahmat, M., Haque, A., Nosheen, S., Ahmad, I., Rasul, S., Role of Enzymatic System of Screened Pleurots ostreatus IBL-02 in the Bio-Removal of Synthetic Dyes Effluent, In: J. Chem. Soc. Pak., 2019, 41, 3, 509-522

[4] Chatha, S.A.S, Kiran, S., Gulzar, T., Kamal, S., Ghaffar, A., Chatha, M.N., Comparative study on decolorisation and mineralization of synthetic and real textile effluents using advanced oxidation processes, In: Oxid. Commun., 2016, 39, 2, 1604-1614 
[5] Kiran, S., Huma, T., Jalal, F., Farooq, T., Hameed, A., Gulzar, T., Bashir, A., Rahmat, M., Rahmat, R., Rafique, M.A., Lignin degrading system of Phanerochaete chrysosporium and its exploitation for degradation of synthetic dyes wastewater, In: Pol. J. Environ. Stud., 2019, 28, 3, 1749-1757

[6] Datta, S., et al, Assessment of antimicrobial effectiveness of natural dyed fabrics, In: Bangladesh J. Sci. Ind. Res, 2013, 48, 3, 179-184

[7] Ado, A., Yahaya, H., Kwalli, A.A., Abdulkadir, R.S., Dyeing of textiles with eco-friendly natural dyes: a review, In: Int. J. Environ. Monit. Assess., 2014, 1, 76-81

[8] Yesmin, M.N., Uddin, S.N., Mubassara, S., Akond, M.A., Antioxidant and antibacterial activities of C. procera Linn, In: American-Eurasian J. Agri. Environ. Sci., 2008, 4, 5, 550-553

[9] Chengaiah, B., et al., Medicinal importance of natural dyes a review, In: Int. J. PharmTech. Res., 2010, 2, 1, 144-154

[10] Kiran, S., et al., Recent trends in textile effluent treatments: A review, In: Advanced Materials for Wastewater Treatment, 2017, 29-49

[11] Adeel, S., et al., Dyeing of gamma irradiated cotton using Direct Yellow 12 and Direct Yellow 27: improvement in colour strength and fastness properties, In: Cellulose, 2015, 22, 2095-2105

[12] Jia, Y., et al., Dyeing characteristics and functionability of tussah silk fabric with oak bark extract, In: Textile Research Journal, 2017, 87, 1806-1817

[13] Gulzar, T., et al., Eco-friendly dyeing of gamma ray induced cotton using natural quercetin extracted from acacia bark (A. nilotica), In: J. Nat. Fibers, 2015, 12, 494-504

[14] Haji, A., Dyeing of Cotton Fabric with Natural Dyes Improved by Mordants and Plasma Treatment. Progress in Color, In: Colorants and Coatings, 2019, 12, 3, 191-201

[15] Adeel, S., Zuber, M., Zia, K.M., Microwave-assisted extraction and dyeing of chemical and bio-mordanted cotton fabric using harmal seeds as a source of natural dye, In: Environmental Science and Pollution Research, 2018, 25, 11100-11110

[16] Haji, A., Nasiriboroumand, M., Qavamnia, S.S., Cotton Dyeing and Antibacterial Finishing Using Agricultural Waste by an Eco-friendly Process Optimized by Response Surface Methodology, In: Fibers and Polymers, 2018, 19, 11, 2359-2364

[17] Adeel, S., Bhatti, I.A., Zahid, M., Saba, S., Modification of cotton fabric for textile dyeing, industrial mercerization versus gamma irradiation, In: J. Text. Inst., 2017, 108, 287-292

[18] Kashyap, Dr.R., Sharma, N.., Lakshmi, S., Divya, Dyeing of Cotton with Natural Dye Extract from Coconut Husk, In: Int. J. Sci. Technol. Engng., 2016, 3, 92-95

[19] Kon, O., Eduok, U., Israel, A., Characterization and phytochemical screening of coconut (Cocos nucifera L.) Coir dust as a low cost adsorbent for waste water treatment, In: Elixir Appl. Chem., 2012, 47, 8961-8968

[20] Dyana, J.P., Kanchana, G., Preliminary phytochemical screening of Cocos nucifera L. flowers, In: International Journal of Current Pharmaceutical Research, 2012, 4, 3-4

[21] Singla, R.K., Jagani, H., Investigation of Antimicrobial Effect of Dry Distilled Extract of Cocos nucifera Linn Endocarp, In: Webmed Central Pharmac. Sci., 2012, 3, WMC002884

[22] Batool, F., et al., Gamma radiations induced improvement in dyeing properties and colorfastness of cotton fabrics dyed with chicken gizzard leaves extracts, In: Rad. Phy. Chem., 2013, 89, 33-37

[23] Adeel, S., et al., Dyeing of cotton fabric using UV irradiated turmeric (Curcuma longa L.) as natural dye, In: Res. J. Text. Apparel, 2011, 15, 71-76

[24] Ferrari, C., et al., Photodegradation of rhodamine $B$ using the microwave $/ \mathrm{UV} / \mathrm{H}_{2} \mathrm{O}_{2}$ : effect of temperature, In: Int. J. Photoen., 2013, 2, 123-127

[25] Khan A.A., et al., Extraction of natural dye from red calico leaves: Gamma ray assisted improvements in colour strength and fastness properties, In: Dyes and Pigments, 2014, 103, 50-54

[26] Israel, A.U., Ogali, R.E., Akaranta, O., Obot, I.B., Extraction and characterization of coconut (Cocos nucifera L.) coir dust, In: Songklanakarin J. Sci. Technol., 2011, 33, 717-724

[27] Doty, K., Haar, S., Kim J., Black walnut, Osage orange and eastern redcedar sawmill waste as natural dyes: effect of aluminum mordant on color parameters. In: Fashion and Text, 2016, 3, 1, 22

[28] Chhipa, M.K., Srivastav, S., Mehta, N., Study of dyeing of cotton fabric using peanut pod natural dyes using $\mathrm{Al}_{2}\left(\mathrm{SO}_{4}\right)_{3}, \mathrm{CuSO}_{4}$ and $\mathrm{FeSO}_{4}$ mordanting agents, In: Int. J. Environ. Agri. Res., 2017, 3, 2, $36-44$

[29] Satyanarayana D.N.V., Chandra K.R., Dyeing of cotton cloth with natural dye extracted from pomegranate peel and its fastness, In: Int. J. Engng Sci. Res. Technol., 2013, 2, 2664-69

[30] Bhatti, I.A., et al., Influence of gamma radiation on the colour strength and fastness properties of fabric using turmeric (Curcuma longa L.) as natural dye, In: Rad. Phys. Chem., 2010, 79, 622-625

[31] Yusuf, M., Mohammad, F., Shabbir, M., Khan, M.A., Eco-dyeing of wool with Rubiacordifolia root extract: Assessment of the effect of Acacia catechu as biomordant on color and fastness properties, In: Text. Cloth. Sustain., 2017, 2, 10

[32] Wang, Y., Lee, C.H., Tang, Y.L., Kan, C.W., Dyeing cotton in alkane solvent using polyethylene glycol-based reverse micelle as reactive dye carrier, In: Cellulose, 2016, 23, 1, 965-980

[33] Hou, A., Wang, X., Wu, L., Effect of microwave irradiation on the physical properties and morphological structures of cotton cellulose, In: Carbohydrate Polym., 2008, 74, 934-937

[34] El-Khatib, E.M., Ali, N.F., Ramadan, M.A., Environmentally friendly dyeing of silk fabrics using microwave heating, In: Int. J. Curr. Microbiol. Appl. Sci., 2014, 3, 757-764 
[35] Sinha, K., Saha, P.D., Datta, S.S., Response surface optimization and artificial neural network modeling of microwave assisted natural dye extraction from pomegranate rind, In: Ind. Crops and Prod., 2012, 37, 1, 408-414

[36] Zhang, X., et al., Anti-hyperlipidemic effects and potential mechanisms of action of the caffeoylquinic acid-rich Pandanus tectorius fruit extract in hamsters fed a high fat-diet, In: PloS one, 2013, 8, 4, 61922

[37] Jose, S., Gurumallesh, H.P., Ammayappan, L., Eco-Friendly dyeing of silk and cotton textiles using combination of three natural colorants, In: J. Nat. Fib., 2017, 14, 1, 40-49

[38] Marie, M.M., Shokry, G.M., El-Khatib, H.S., Shahin, M.F., One bath cationization and dyeing of cotton fabric with Brazilwood natural dye, In: Int. J. Innov. Appl. Studies, 2015, 11, 928

[39] Periolatto, M., Ferrero, F., Migliavacca, G., Low temperature dyeing of wool fabric by acid dye after UV irradiation, In: The J. Text. Inst., 2014, 105, 10, 1058-1064

[40] Sun, S.S., Tang, R.C., Adsorption and UV protection properties of the extract from honeysuckle onto wool, In: Ind. Engng. Chem. Res., 2011, 50, 4217-4224

[41] Yusuf, M., et al., Dyeing studies with henna and madder: A research on effect of tin (II) chloride mordant, In: J. Saud. Chem. Soc., 2015, 19, 1, 64-72

[42] Iqbal, J., Bhatti, I.A., Adeel, S., Effect of UV radiation on dyeing of cotton fabric with extracts of henna leaves, 2008

[43] Adeel, S., Hanif, I., Zuber, M., Muneer, M., Ecofriendly Dyeing of UV-Irradiated Cotton Using Extracts of Acacia nilotica Bark (Kikar) as Source of Quercetin, In: Asian Journal of Chemistry, 2014, 26, 830-834

[44] Büyükakinci, B.Y., Investigation of antibacterial activities of tin ions on wool fabric, In: Industria Textila, 2013, 64, 5, 241-245

[45] Rather, L.J., et al., Ecological dyeing of Woolen yarn with Adhatodavasica natural dye in the presence of biomordants as an alternative copartner to metal mordants, In: J. Environ. Chem. Engng., 2016, 4, 3041-3049

[46] Adeel, S., et al, Microwave-assisted sustainable dyeing of wool fabric using cochineal-based carminic acid as natural colorant, In: J. Nat. Fiber, 2018, 1-9

[47] İşmal, Q.E., Greener natural dyeing pathway using a by-product of olive oil; prina and biomordants, In: Fibers and Polym., 2017, 18, 4, 773-785

[48] Ajmal, M., Modulation of pomegranate peel colourant characteristics for textile dyeing using high energy radiations, In: Ind. Crops and Production, 2014, 58, 188-193

Authors:

SHUMAILA KIRAN ${ }^{1}$, SHAHID ADEEL ${ }^{1}$, MUHAMMAD SAJJAD YOUSAF ${ }^{1}$, NOMAN HABIB ${ }^{2}$, ATYA HASSAN ${ }^{3}$, MUHAMMAD ABDUL QAYYUM ${ }^{4}$, MUHAMMAD ABDULLAH ${ }^{5}$

${ }^{1}$ Department of Applied Chemistry, Government College University, Faisalabad, Pakistan e-mail: shahidadeel@gcuf.edu.pk, msajjadyousaf1988@gmail.com

${ }^{2}$ Department of Botany, Government College University, Faisalabad, Pakistan e-mail: nomi4442003@yahoo.com

${ }^{3}$ Department of Chemistry, Federal Urdu University of Arts, Science and Technology, Gulshan-e-lqbal, Karachi, Pakistan e-mail: atya007chem@gmail.com

${ }^{4}$ Department of Chemistry, Division of Science \&Technology, University of Education Lahore, Pakistan e-mail: qayyumkh12@yahoo.com

${ }^{5}$ Department of Biochemistry, Government College University, Faisalabad, Pakistan e-mail: 234abdullah@gmail.com

Corresponding author:

\section{SHUMAILA KIRAN}

e-mail: shumaila.asimch@gmail.com 